\title{
Phylogeny of the Genus Corynebacterium Deduced from Analyses of Small-Subunit Ribosomal DNA Sequences
}

\author{
RAYMOND RUIMY, ${ }^{1 *}$ PHILIPPE RIEGEL, ${ }^{2}$ PATRICK BOIRON,${ }^{3}$ \\ HENRI MONTEIL, ${ }^{2}$ AND RICHARD CHRISTEN ${ }^{1}$ \\ Centre National de la Recherche Scientifique and Université Paris 6, Station Zoologique, Villefranche \\ sur mer 06230, ${ }^{1}$ Laboratoire de Bactériologie de la faculté de Médecine, F-67000 Strasbourg, ${ }^{2}$ \\ and Unité de Mycologie, Institut Pasteur, 75724 Paris Cedex $15{ }^{3}$ France
}

\begin{abstract}
We determined almost complete small-subunit ribosomal DNA sequences of 50 reference strains belonging to the genera Corynebacterium, Rhodococcus, and Gordona and compared these sequences with previously publishedl sequences. Three phylogenetic methods (the neighbor-joining, maximum-likelihood, and maximumparsimony methods), as well as a bootstrap analysis, were used to assess the robustness of each topology which we obtained. The results of comparative phylogenetic analyses confirmed that the genera Corynebacterium, Dietzia, Gordona, Mycobacterium, Nocardia, Tsukamurella, and Turicella form a monophyletic taxon within the phylum containing the high-G+C-content gram-positive bacteria. The genus Corynebacterium appeared to be a monophyletic unit whose members could be divided into four major clusters. The validity of the genus Turicella is doubtful since members of this genus clearly belong to the genus Corynebacterium. The variability of chemotaxonomic characteristics within the genus Corynebacterium suggests that small-subunit ribosomal DNA sequence analysis is probably the most straightforward method for confirming that a bacterium belongs to this genus.
\end{abstract}

The actinomycetes that are characterized by cell wall chemotype IV (cell walls containing meso-diaminopimelic acid as the diamino acid and arabinose and galactose as the major sugars [26]) and contain mycolic acids include many organisms that are pathogens for humans and animals. The results of small-subunit ribosomal DNA (rDNA) cataloging $(13,47,48)$, rDNA-DNA hybridization (28), and small-subunit rDNA sequence (41) analyses support the hypothesis that there is a robust monophyletic taxon (the CMN group) that includes all of these bacteria. The chemotaxonomic profile and $\mathrm{G}+\mathrm{C}$ contents of these organisms led to the description of six genera organized in the following three families (15): Mycobacteriaceae (containing the single genus Mycobacterium), Corynebacteriaceae (containing the single genus Corynebacterium), and Nocardiaceae (containing four genera, the genera Nocardia, Rhodococcus, Gordona, and Tsukamurella). In contrast, the results of small-subunit rDNA cataloging (13) and rDNADNA hybridization (28) analyses revealed only two families, the family Mycobacteriaceae (containing the genera Mycobacterium, Nocardia, and Rhodococcus) and the family Corynebacteriaceae (containing the single genus Corynebacterium). Complete rRNA descriptions are now available for the genera Mycobacterium (30, 40, 49), Rhodococcus, Gordona, and Nocardia $(6,24,25,31-33,41)$. Recently, the genus Dietzia was created for the single species Rhodococcus maris, which is now named Dietzia maris (33). Despite recent taxonomic revisions of several Rhodococcus species (Table 1), all of the remaining Rhodococcus species were not grouped in a monophyletic taxon but were placed in six groups on the basis of smallsubunit rDNA analysis results (31). The genera Gordona and Nocardia constituted two monophyletic taxa after exclusion of "Nocardia amarae," which was transferred to the genus Gordona, and transfer of Rhodococcus aichiensis to the genus Gordona as Gordona aichiensis; these transfers were supported by chemotaxonomic data $(17,25,41)$. Detailed information con-

* Corresponding author. Phone: (33) 937637 80. Fax: (33) 937638 93. Electronic mail address: ruimy@ccrv.obs-vlfr.fr. cerning phylogenetic relationships among members of the genus Corynebacterium is still not available, however, because small-subunit rDNA sequences have not been determined for a sufficient number of species. To help resolve phylogenetic relationships within the genus Corynebacterium and to examine the phylogenetic position of this genus within the CMN group, we determined nearly complete sequences of the small-subunit rDNAs of 50 reference strains belonging to the genera Corynebacterium, Rhodococcus, and Gordona. We combined our data with previously published data, and we discuss our results in terms of chemotaxonomy in an attempt to describe intrageneric relationships within the genus Corynebacterium and intergeneric relationships with other closely related taxa.

\section{MATERIALS AND METHODS}

Bacterial strains. We determined the small-subunit rDNA sequences of Corynebacterium, Rhodococcus, and Gordona strains whose small-subunit rDNA sequences were not available when this study was initiated; the strains which we used are listed in Table 1. Table 1 also shows the sources of strains and EMBL accession numbers. The culture medium and culture conditions used were the medium and conditions recommended in the American Type Culture Collection Catalogue of Bacteria and Bacteriophages (1).

PCR amplification and small-subunit rDNA sequencing. The method used to prepare bacterial DNA for PCR was derived from the method of Sritharan and Barker (46). Colonies were suspended in $200 \mu \mathrm{l}$ of a lysis solution $(10 \mathrm{mM}$ Tris-HCl, 1 mM EDTA, $1 \%$ Triton X-100; pH 8), heated for $5 \mathrm{~min}$ at $100^{\circ} \mathrm{C}$, and then transferred on ice. After a single chloroform extraction, $5 \mu$ l of supernatant was used in a PCR to amplify the small-subunit rDNA genes. Two pairs of primers were used; the members of one pair corresponded to positions 8 to 28 and 1498 to 1509 on the Escherichia coli small-subunit rDNA sequence, and the members of the other pair corresponded to positions 8 to 28 and 1384 to 1400 . The procedures used for PCR amplification and sequencing of PCR products have been described previously (42)

Phylogenetic analysis and alignment: general procedure. The phylogenetic data described below were obtained (i) by using successive alignment and phylogeny procedures and (ii) by reinvestigating deep branching patterns after close relationships were determined. In each phylogenetic analysis, we restricted the comparisons to nucleotide positions that were aligned without doubt. Some analyses were performed several times, with or without small domains that could have reached the point of saturation for mutations. Although this approach was probably not as efficient as carefully weighting each position independently, it was easier and was probably a reasonable compromise considering the possible 
TABLE 1. Sources and EMBL accession numbers for small-subunit rDNA sequences of the bacteria sequenced in this study

\begin{tabular}{|c|c|c|c|c|c|}
\hline $\operatorname{Taxon}^{a}$ & Source $^{b}$ & Strain & ATCC no. & EMBL $^{c}$ & $\overline{\text { Reference }(\mathrm{s})^{d}}$ \\
\hline $\begin{array}{l}\text { Connebacterium afermentans subsp. } \\
\text { afermentans }\end{array}$ & $\mathrm{CIP}$ & CIP $103499^{\mathrm{T}}$ & & $\mathrm{X} 82054$ & \\
\hline $\begin{array}{l}\text { Connebacterium afermentans subsp. } \\
\text { liphophilum }\end{array}$ & CIP & CIP $103500^{\mathrm{T}}$ & & X82055 & \\
\hline Corynebacterium ammoniagenes & $\mathrm{CIP}$ & CIP $101283^{\mathrm{T}}$ & ATCC $6871^{\mathrm{T}}$ & X82056 & \\
\hline Corynebacterium amycolatum & CIP & CIP $103452^{\mathrm{T}}$ & ATCC $49368^{\mathrm{T}}$ & X82057 & \\
\hline "Corynebacterium asperum" & CIP & CIP 52.13 & & X82050 & \\
\hline Corynebacterium bovis & NCTC & NCTC $3224^{\mathrm{T}}$ & ATCC $7715^{T}$ & X82051 & \\
\hline "Corynebacterium hoagii" & ATCC & & ATCC $7005^{T}$ & X82052 & \\
\hline Corynebacterium callunae & CCUG & CCUG 28793 & ATCC $15991^{\mathrm{T}}$ & $\mathrm{X} 82053$ & \\
\hline Corynebacterium cystitidis & CIP & CIP $103424^{\mathrm{T}}$ & ATCC $29593^{\mathrm{T}}$ & X82058 & \\
\hline Corynebacterium diphtheriae & CIP & $\mathrm{CIP} 100721^{\mathrm{T}}$ & ATCC $27010^{\mathrm{T}}$ & $\mathrm{X} 82059$ & \\
\hline Corynebacterium flavescens & CIP & CIP $69.5^{\mathrm{T}}$ & ATCC $10340^{\mathrm{T}}$ & $\mathrm{X} 82060$ & \\
\hline Corynebacterium glutamicum & IAM & IAM $12435^{\mathrm{T}}$ & ATCC $13032^{\mathrm{T}}$ & $\mathrm{X} 82061$ & \\
\hline Corynebacterium jeikeium & CIP & CIP $103337^{\mathrm{T}}$ & ATCC $43734^{\mathrm{T}}$ & $\mathrm{X} 82062$ & \\
\hline Corynebacterium kutscheri & CIP & CIP $103423^{\mathrm{T}}$ & ATCC $15677^{\mathrm{T}}$ & X82063 & \\
\hline Corynebacterium matruchotii & CIP & CIP $81.82^{\mathrm{T}}$ & ATCC $14266^{\mathrm{T}}$ & X82065 & \\
\hline Corynebacterium minutissimum & NCTC & NCTC $10288^{\mathrm{T}}$ & ATCC $23348^{\top}$ & $\mathrm{X} 82064$ & \\
\hline Corynebacterium mycetoides & CIP & CIP $55.51^{\mathrm{T}}$ & ATCC $21134^{\mathrm{T}}$ & $\mathrm{X} 82066$ & \\
\hline Corynebacterium pilosum & ATCC & & ATCC $29592^{\mathrm{T}}$ & X81908 & \\
\hline Corynebacterium propinquum & CIP & CIP $103792^{\mathrm{T}}$ & & X81917 & \\
\hline Corynebacterium pseudodiphtheriticum & CIP & CIP $103420^{\mathrm{T}}$ & ATCC $10700^{\mathrm{T}}$ & X81918 & \\
\hline Corynebacterium pseudotuberculosis biovar ovis & CIP & CIP $102968^{\mathrm{T}}$ & ATCC $19410^{\mathrm{T}}$ & X81916 & \\
\hline Corynebacterium pseudotuberculosis biovar equi & CIP & CIP 52.97 & & X81907 & \\
\hline Corynebacterium renale & CIP & CIP $103421^{\mathrm{T}}$ & ATCC $19412^{\mathrm{T}}$ & X81909 & \\
\hline Corynebacterium sp. CDC group F1 taxon 1 & $\mathrm{CDC}$ & CDC G4330 & & X81905 & \\
\hline Corynebacterium sp. CDC group F1 taxon 2 & $\mathrm{CDC}$ & CDC G5911 & & X81904 & \\
\hline Corynebacterium striatum & CIP & CIP $81.15^{\mathrm{T}}$ & ATCC $6940^{\mathrm{T}}$ & X81910 & \\
\hline Corynebacterium ulcerans 1 & CIP & CIP 54.53 & & X81912 & \\
\hline Corynebacterium ulcerans 2 & CCUG & CCUG $2708^{\mathrm{T}}$ & ATCC $51799^{\mathrm{T}}$ & X81911 & \\
\hline Corynebacterium urealyticum & ATCC & & ATCC $43042^{\mathrm{T}}$ & X81913 & \\
\hline Corynebacterium xerosis 1 & ATCC & & $\operatorname{ATCC} 373^{\mathrm{T}}$ & X81914 & \\
\hline Corynebacterium xerosis 2 & IAM & IAM 12431 & ATCC 7711 & X81906 & \\
\hline Dietzia maris (formerly Rhodococcus maris) & ATCC & & ATCC $35013^{\mathrm{T}}$ & X81920 & 33 \\
\hline $\begin{array}{l}\text { Gordona aichiensis (formerly Rhodococcus } \\
\text { aichiensis) }\end{array}$ & ATCC & & $\operatorname{ATCC} 33611^{\mathrm{T}}$ & X81925 & 25 \\
\hline Gordona bronchialis & $\mathrm{CIP}$ & CIP $1780.88^{\mathrm{T}}$ & ATCC $25592^{\mathrm{T}}$ & X81919 & \\
\hline Gordona rubropertinctus & ATCC & & ATCC $25593^{\mathrm{T}}$ & X81915 & \\
\hline Gordona sputi 1 & CIP & CIP $1833.89^{\mathrm{T}}$ & ATCC $29627^{\mathrm{T}}$ & X81923 & \\
\hline Gordona sputi 2 & CIP & CIP 1835.89 & & X81924 & \\
\hline $\begin{array}{l}\text { Gordona sputi } 3 \text { (formerly Rhodococcus } \\
\text { chubuensis) }\end{array}$ & CIP & CIP 1781.88 & ATCC 33609 & $\mathrm{X} 81927$ & 36 \\
\hline Gordona terrae & ATCC & & ATCC $25594^{\mathrm{T}}$ & X81922 & \\
\hline $\begin{array}{l}\text { Mycobacterium chlorophenolicum (formerly } \\
\text { Rhodococcus chlorophenolicus) }\end{array}$ & NCIMB & NCIMB $12325^{\mathrm{T}}$ & & X81926 & 4,20 \\
\hline Rhodococcus coprophilus & ATCC & & ATCC $29080^{\mathrm{T}}$ & X81928 & \\
\hline Rhodococcus erythropolis & ATCC & & ATCC $4277^{\mathrm{T}}$ & X81929 & \\
\hline Rhodococcus fascians & ATCC & & ATCC $12974^{\mathrm{T}}$ & $\mathrm{X} 81930$ & \\
\hline $\begin{array}{l}\text { Rhodococcus fascians (formerly Rhodococcus } \\
\text { luteus) }\end{array}$ & ATCC & & ATCC 35014 & X81932 & 24 \\
\hline Rhodococcus globerulus & NCIMB & NCIMB $12315^{\mathrm{T}}$ & & X81931 & \\
\hline Rhodococcus marinonascens & ATCC & & ATCC $35653^{\mathrm{T}}$ & X81933 & \\
\hline Rhodococcus rhodnii & ATCC & & ATCC $35071^{\mathrm{T}}$ & X81935 & \\
\hline Rhodococcus rhodochrous 1 & CIP & CIP $1759.88^{\mathrm{T}}$ & ATCC $13808^{\mathrm{T}}$ & X81936 & \\
\hline $\begin{array}{l}\text { Rhodococcus rhodochrous } 2 \text { (formerly } \\
\text { Rhodococcus roseus) }\end{array}$ & ATCC & & ATCC 271 & X81921 & 32 \\
\hline Rhodococcus zopfii & ATCC & & ATCC $51349^{\top}$ & X81934 & \\
\hline
\end{tabular}

${ }^{a}$ Quotations marks indicate that an organism has been reassigned to a different genus or species.

${ }^{b}$ Collections from which the bacteria were obtained. ATCC, American Type Culture Collection, Rockville, Md.; CCUG, Culture Collection of the University of Göteborg, Göteborg, Sweden; CDC, Centers for Disease Control and Prevention, Atlanta, Ga.; CIP, Collection Institut Pasteur, Paris, France; IAM, Institute of Applied Microbiology, Tokyo, Japan; NCTC, National Collection of Type Cultures, London, United Kingdom; NCIMB, National Collection of Industrial and Marine Bacteria, Aberdeen, United Kingdom.

"EMBL accession numbers for small-subunit rDNA sequences.

${ }^{d}$ Papers published while this work was in progress, in which sequences are described and phylogenetic positions are analyzed. 
problems of crossing-over that might affect some of the sequences investigated (45).

We also performed some analyses several times by including and excluding particular species that had high rates of mutation or that were distant outgroups. Inclusion of distantly related outgroups brings random noise into an analysis and does not allow resolution of the relationships among the more closely related species (44). Long branches for ingroups have the same effect as distant outgroups (that is, they bring noise into a phylogenetic analysis). Thus, monophyletic units containing such species are unstable because of highly variable sequences, and their presence can also affect neighboring taxa. To alleviate this problem, we performed phylogenetic analyses successively with all outgroups or with a set of outgroups restricted to the closest relatives, with or without ingroups that were characterized by long branches.

Because we wanted to keep computation time for each phylogenetic analysis within reasonable limits, it was not possible to include all representatives of the outgroups and ingroups in maximum-parsimony and maximum-likelihood analyses. Instead, we performed multiple analyses by using different outgroups and different ingroups (as determined by the neighbor-joining analysis). All sequence alignment and species selection operations were done by using computer programs developed by us and available on request from $\mathrm{R}$. Christen.

Phylogenetic methods. A neighbor-joining method (43) was used in our preliminary analysis; the resulting topologies were then further investigated by using maximum-likelihood and maximum-parsimony methods. For the maximum-likelihood analyses we used the fdnaml program rewritten by G. J. Olsen (University of Illinois, Urbana) and compiled on a Hewlett-Packard model 700 workstation, while for the maximum-parsimony analyses we used the "PAUP" program for the Macintosh (51). The robustness of each topology was evaluated with a maximum-parsimony method through 100 bootstrap replications (heuristic search). Trees were constructed by using the njplot program for the Macintosh developed by M. Gouy (Université Claude Bernard, Lyon, France), which allows transformation of a formal tree representation (Newick's format) into MacDraw drawings.

Only topologies that were found to be similar by all three methods were retained as true trees. The results of recent theoretical work have demonstrated that convergence of the results of all three methods is a very robust indication that the correct phylogeny has been determined $(21,23)$.

Domains used. Different parts of the small-subunit rDNA sequences were used to prepare Fig. 1 and 2 and Table 2. The positions used for Fig. 1 correspond to positions 6 to 42,91 to 145,193 to 412,441 to 558,565 to 595,600 to 782,801 to 949,984 to 1082,1088 to 1206,1214 to 1234 , and 1244 to 1320 in the sequence of Corynebacterium amycolatum. The positions used for Fig. 2 corre spond to $C$. amycolatum positions 201 to 272,276 to 348,350 to 402,441 to 557 , 569 to 595,598 to 782,802 to 900,921 to 949,984 to 1080,1092 to 1201,1214 to 1232 , and 1244 to 1310 . And the positions used for Table 2 correspond to $C$ amycolatum positions 2 to 48,60 to 156,174 to 422 , and 428 to 1320 .

Nucleotide sequence accession numbers. The EMBL accession number for the nucleotide sequence of $C$. amycolatum is X82057. Other EMBL accession numbers are shown in Table 1.

\section{RESULTS AND DISCUSSION}

Phylogenetic relationships within the genus Corynebacterium. Relationships within the genus Corynebacterium were studied in our phylogenetic analyses by using Tsukamurella paurometabolum and Dietzia maris as the outgroups closest to this genus. The results of these analyses demonstrated that there are four major clades in this genus (clusters I through IV) (Fig. 1).

Cluster IV contained C. amycolatum, "Corynebacterium asperum," and Corynebacterium xerosis ATCC $373^{\mathrm{T}}(\mathrm{T}=$ type strain) in a robust clade (bootstrap value, 99\%) that was a sister group to all other corynebacteria (including Turicella otitidis) (Fig. 1). Because they exhibit a level of DNA-DNA relatedness that is greater than $90 \%$ (37), "C. asperum" and $C$. amycolatum are subjective synonyms. In contrast, $C$. xerosis ATCC $373^{\mathrm{T}}$ contains mycolic acids and is thus strikingly different chemotaxonomically from $C$. amycolatum and "C. asperum," which lack mycolic acids $(3,7)$.

Cluster III was identified as a branch that contained Corynebacterium bovis, Corynebacterium jeikeium, Corynebacterium urealyticum, and Corynebacterium variabilis. The robustness of this clade is doubtful as it was identified only by the neighborjoining and maximum-likelihood methods and was not supported by bootstrap data. However, these four species all have high $\mathrm{G}+\mathrm{C}$ contents, which range from $61 \mathrm{~mol} \%(C$. jeikeium $)$

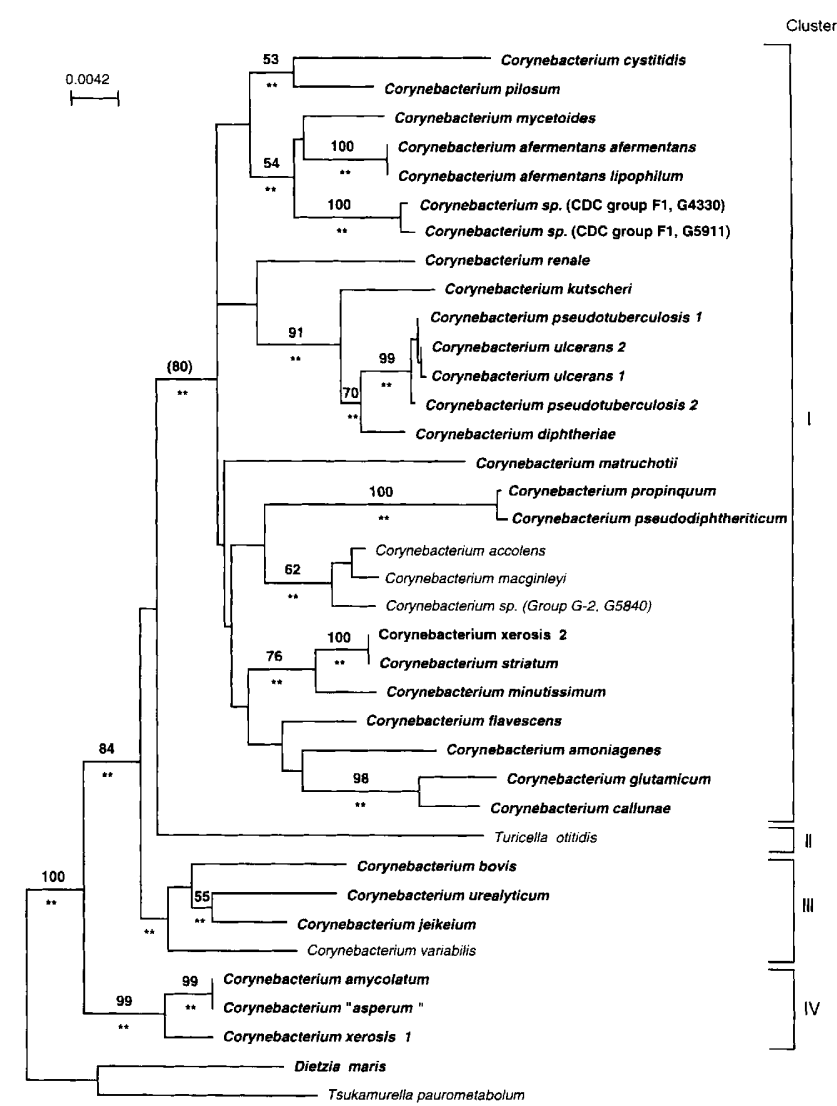

FIG. 1. Phylogenetic relationships among Corynebacterium species: unrooted tree obtained by using a neighbor-joining method. The double asterisks indicate branches that were also identified by a maximum-likelihood method $(P<0.01)$. The values (expressed as percentages) above the lines (only values greater than $50 \%$ are shown) mark branches also found in the most-parsimonious tree and indicate how these branches are supported by bootstrap data (heuristic search). The number in parentheses indicates the percentage of bootstrap replications when Turicella otitidis was omitted from the analysis. Bar = number of accumulated changes per nucleotide. The names of organisms sequenced in this study are in boldface type.

to $74 \mathrm{~mol} \%$ (C. bovis), and all except $C$. jeikeium have tuberculostearic acid in their cell walls. $C$. jeikeium and $C$. urealyticum, which are closely related as determined by all three phylogenetic methods (a conclusion supported by only moderate bootstrap values) have the same respiratory type (strictly aerobic) and are resistant to the same antibiotics.

Turicella otitidis appeared to be an isolated species that we placed in a separate cluster (cluster II) (see below).

All of the remaining Corynebacterium species formed a monophyletic unit (cluster I) that was supported by the results of all three phylogenetic methods and a moderate bootstrap value $(40 \%)$. The bootstrap value was $80 \%$ when Turicella otitidis was excluded from the analyses (data not shown). The peculiar rate of mutation of Turicella otitidis (14) is probably responsible for the unstableness of this cluster. Within this monophyletic unit, six taxa were identified by all three phylogenetic methods and by high bootstrap values. Corynebacterium cystitidis and Corynebacterium pilosum, which are pathogens of cows and previously were known as biotypes of Corynebacterium renale, were found to be closely related by all three phylogenetic methods, which was consistent with the DNA-DNA relatedness values (60 to 63\%) (53). Two recently characterized subspecies of Corynebacterium afermentans rep- 


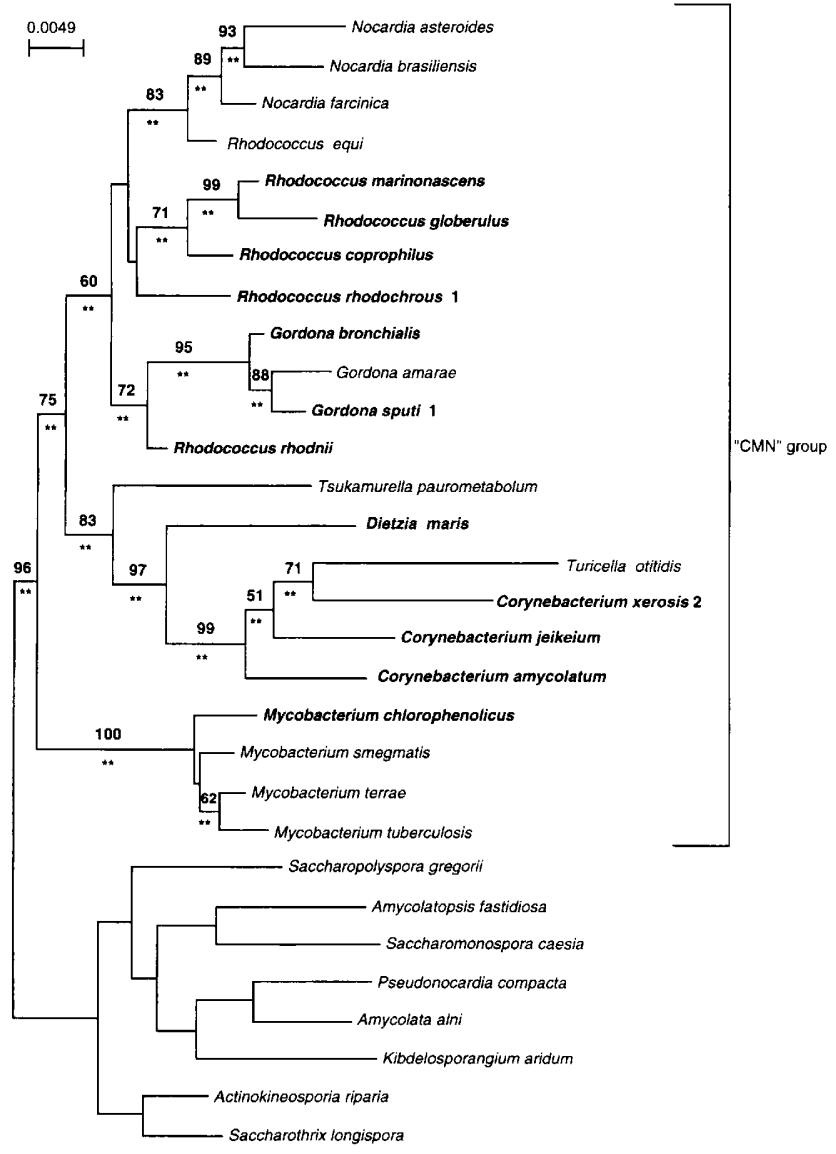

FIG. 2. Phylogenetic position of the genus Corynebacterium within the CMN group. For an explanation see the legend to Fig. 1. The branch robustness is not indicated for the outgroups. The genus Corynebacterium and Turicella otitidis form a well-defined and robust monophyletic unit related to $D$. maris.

resenting Centers for Disease Control (CDC) coryneform absolute nonfermenter group 1 (35), Corynebacterium mycetoides, and two Corynebacterium sp. strains (CDC group F1 strains G4330 and G5911), formed a monophyletic unit that was supported by moderate bootstrap values but was consistent with DNA-DNA hybridization data which revealed that $C$. afermentans subsp. afermentans and C. afermentans subsp. lipophilum were more closely related to $C$. mycetoides (levels of DNA relatedness, 24 and $40 \%$, respectively) than to any other Corynebacterium spp., while C. afermentans subsp. afermentans and Corynebacterium sp. CDC group F1 strain G5911 exhibited a DNA relatedness value of $21 \%$ (35). A monophyletic unit composed of Corynebacterium kutscheri, Corynebacterium diphtheriae, two strains of Corynebacterium pseudotuberculosis, and two strains of Corynebacterium ulcerans was supported by a high bootstrap value $(91 \%)$, which confirmed numerical taxonomy data (22). Because of the presence of rhamnose in its cell wall and its low $\mathrm{G}+\mathrm{C}$ content $(46$ to $46.2 \mathrm{~mol} \%)(12,29)$, the position of $C$. kutscheri in the genus Corynebacterium has been doubted for a long time. The results of our rDNA phylogenetic analyses clearly confirmed that this organism should be included in the genus Corynebacterium and were consistent with data which showed that rhamnose is not present in the cell wall of $C$. kutscheri ATCC $15677^{\mathbf{T}}$ (5). A close relationship (but not species identity) between the two strains of $C$. pseudotuberculosis and $C$. ulcerans confirmed DNA-DNA relatedness data (39) and was consistent with the finding that the phenotypes of these organisms differ only in the production of acid from glycogen. The presence of $C$. diphtheriae in this cluster is not surprising because $C$. diphtheriae, $C$. pseudotuberculosis, and $C$. ulcerans all have the following characteristics that distinguish them from all other members of the genus: (i) the ability to produce diphtheria toxin if they are lysogenized by a suitable bacteriophage (19), (ii) a common fatty acid pattern (9), and (iii) the ability to produce neuraminidase but not pyrazinamidase (2). Corynebacterium propinquum, which was recently proposed as the species name for CDC coryneform absolute nonfermenter group 3 (34), and Corynebacterium pseudodiphteriticum, which differs phenotypically from C. propinquum only by a positive urease test, formed a tight cluster supported by bootstrap analysis data at a confidence level of $100 \%$ (the rDNA sequences exhibited a level of similarity of $99.4 \%)$. This result is consistent with the level of DNA relatedness between these two species (25\%) (34). The existence of a monophyletic unit containing Corynebacterium accolens, Corynebacterium macginleyi, and Corynebacterium sp. CDC group G-2 strain G5840 has recently been confirmed by DNADNA hybridization and small-subunit rDNA sequence data (38). In this study, 45 of 51 human lipophilic diphtheroids were divided into five genomic groups, which in our study were represented by Corynebacterium sp. CDC group G-2 strain G5840, C. accolens, C. macginleyi, Corynebacterium sp. CDC group F1 strain G4330, and Corynebacterium sp. CDC group F1 strain G5911. A close relationship (but not species identity) between the last two strains, which exhibited a level of DNA relatedness of $35 \%$, was supported by our data. Corynebacterium minutissimum, Corynebacterium striatum, and $C$. xerosis IAM 12431 also formed a monophyletic unit (bootstrap value, $76 \%$ ). The exclusion from this cluster of C. xerosis ATCC $373^{\mathrm{T}}$ (closely related to $C$. amycolatum) was consistent with the heterogeneity observed with the $C$. xerosis strains available. Whole-cell fatty acids data, DNA hybridization data (qualitative data obtained by dot blot analysis), and biochemical reaction data (11) showed that 10 strains of $C$. xerosis could be separated into six groups. C. xerosis IAM 12431 and ATCC $373^{\mathrm{T}}$ belonged to two distinct groups, whereas three other strains of $C$. xerosis were indistinguishable from $C$. striatum. Since the small-subunit rDNA sequence of C.xerosis IAM 12431 differed by only three nucleotides from the sequence of C. striatum, $C$. xerosis IAM 12431 could belong to $C$. striatum. However, quantitative DNA hybridization between these two strains will be necessary to confirm this possibility. C. minutissimum and $C$. striatum are part of the normal flora of the human skin and mucosa. These organisms have the same cellular fatty acids, but they differ phenotypically by the presence of nitrate reductase and acid formation from maltose and they have different rDNA sequences (Table 2). A close relationship (but not species identity) between Corynebacterium callunae and Corynebacterium glutamicum was expected because of the level of genomic DNA relatedness of these organisms $(37 \%)$ (27).

Phylogenetic position of the genus Corynebacterium within the CMN group. The genera Corynebacterium, Gordona, Rhodococcus, Dietzia, Nocardia, Mycobacterium, Tsukamurella, and Turicella formed a monophyletic taxon (the CMN group) within the high-G+C-content gram-positive phylum independently of the species selected as outgroups or ingroups and of the phylogenetic methods used, confirming previous findings $(10,13,18,28,41,47,48)$. All species except Turicella otitidis and $C$. amycolatum have cell wall chemotype IV and contain mycolic acids. Therefore, we studied the position of the genus Corynebacterium in this group by using the closest outgroups 


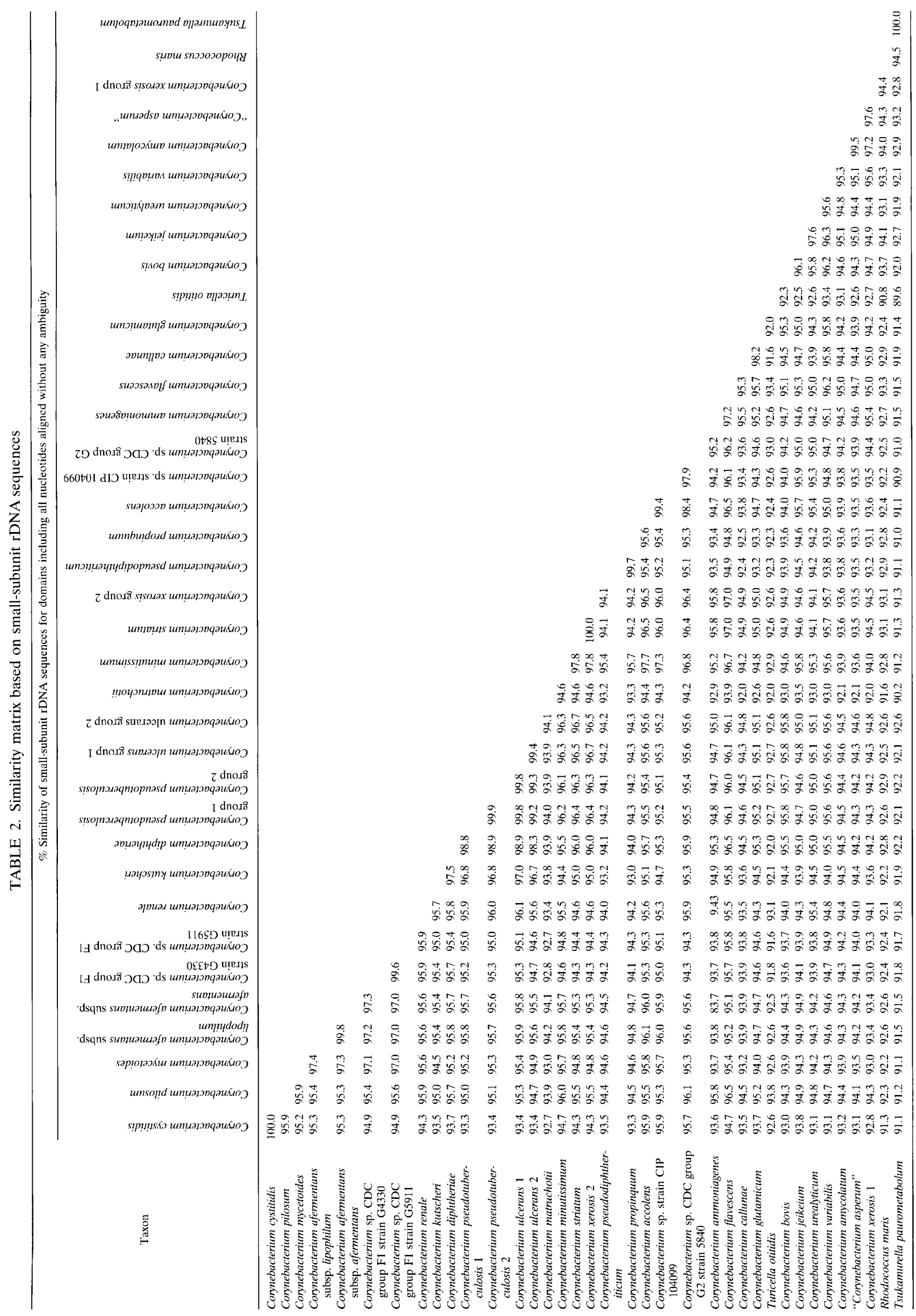


$(41,52)$ to root the CMN group (Fig. 2). The genera Gordona, Rhodococcus, and Nocardia formed a well-defined clade with Rhodococcus species as deep branches. This result confirmed previously published data (31) and suggests that phenotypic traits used to define the genus Rhodococcus might be ancestral characters for these three genera. Numerical taxonomy, chemotaxonomy (16), DNA-DNA hybridization (50), and rDNA sequence data confirmed that "Corynebacterium hoagii" is a synonym of Rhodococcus equi. Despite the heterogeneity observed in the genus Rhodococcus, all of the true Nocardia species formed a monophyletic unit supported by the results of all phylogenetic methods and by high bootstrap values, in agreement with the results of recent detailed phylogenetic studies $(6,31,41)$ and chemotaxonomic data (15). All Gordona species also grouped in a robust cluster supported by the results of all phylogenetic methods and by high bootstrap values. The level of rDNA similarity between $G$. aichiensis (25) and Gordona sputi is more than $99 \%$, but there is less than $20 \%$ genomic DNA-DNA relatedness as determined by an S1 nuclease procedure (37).

All Corynebacterium species plus Turicella otitidis formed a robust monophyletic taxon that was a sister group of the cluster described previously (Fig. 2). The following three taxa were identified because they were supported by the results of all phylogenetic methods and by high bootstrap values: (i) $T s u k a-$ murella paurometabolum, (ii) D. maris, and (iii) the genus Corynebacterium (including Turicella otitidis). Turicella otitidis was clearly included in the monophyletic unit that comprised all of Conynebacterium species and never appeared as a deep branch within this genus. This species was elevated to the genus level on the basis of two chemical characteristics (a lack of mycolic acids and the presence of MK-10 and MK-11 as the predominant menaquinones) and by using a phylogeny based on the results of a single neighbor-joining analysis that included only three Corynebacterium type species (14). This classification was not confirmed by the results of our analyses, which involved three phylogenetic methods, a bootstrap analysis, and all of the Corynebacterium type species. Because Turicella otitidis exhibited an extremely broad range of dissimilarity values (Table 2) compared with all other bacteria, it is likely that the phylogenetic position of Turicella otitidis is easily perturbed in a neighbor-joining analysis by the well-known phenomenon of long-branch attraction. In fact, the predominant type of menaquinone remains the single chemical characteristic that distinguishes Turicella otitidis from other Corynebacterium species, as $C$. amycolatum (a true Corynebacterium species) also lacks mycolic acids (7). Because the menaquinone compositions of all Corynebacterium species have not been determined, the validity of the separate genus Turicella is doubtful; however, it would be prudent to obtain data for all species before the taxonomic status of Turicella otitidis is revised.

In conclusion, the results of our analyses of rDNA sequences confirmed that several species that do not possess the characteristic features of the genus Corynebacterium as outlined by Collins and Cummins (8) should be included in this genus. The initial range of $\mathrm{G}+\mathrm{C}$ contents established for this genus (51 to $65 \mathrm{~mol} \%$ ) should therefore be extended to 46 to $74 \mathrm{~mol} \%$ ( $C$. mycetoides, $68 \mathrm{~mol} \%$; C. afermentans, 66 to $68 \mathrm{~mol} \%$; C. bovis, $74 \mathrm{~mol} \%$; C. variabilis, $65 \mathrm{~mol} \%$; C. xerosis, $71 \mathrm{~mol} \%$; and $C$. kutscheri, $46 \mathrm{~mol} \%$ ). Because $C$. amycolatum and possibly $T u$ ricella otitidis are included in the genus Corynebacterium, the presence of mycolic acids in the cell wall is not a requirement for members of the genus Corynebacterium. Moreover, the genus Corynebacterium is the only genus in the CMN group that is not characterized by the presence of a unique major menaquinone and fatty acid type (8). The heterogeneity of these chemical characteristics probably explains why it is difficult to identify newly isolated bacteria as members of this genus. Because the genus Corynebacterium forms a clear monophyletic unit, small-subunit rDNA sequence analysis is probably the most straightforward method for confirming that a bacterium belongs to this genus.

\section{REFERENCES}

1. American Type Culture Collection. 1992. American Type Culture Collection catalogue of bacteria and bacteriophages, 18th ed. American Type Culture Collection, Rockville, Md.

2. Barksdale, L. 1981. The genus Corynebacterium, p. 1827-1837. In M. P. Starr, H. Stolp, H. G. Trüper, A. Balows, and H. G. Schlegel (ed.), The prokaryotes, vol. 2. Springer-Verlag, New York.

3. Barreau, C., F. Bimet, M. Kiredjian, N. Rouillon, and C. Bizet. 1993. Comparative chemotaxonomic studies of mycolic acid-free coryneform bacteria of human origin. J. Clin. Microbiol. 31:2085-2090.

4. Briglia, M., R. I. L. Eggen, D. J. Van Eslas, and W. M. De Vos. 1994 Phylogenetic evidence for transfer of pentachlorophenol-mineralizing Rhodococcus chlorophenolicus PCP- $\mathrm{I}^{\mathrm{T}}$ to the genus Mycobacterium. Int. J. Syst. Bacteriol. 44:494-498.

5. Bruce, D. L., J. E. Bismanis, and J. M. Vickerstaff. 1969. Comparative examinations of virulent Corynebacterium kutscheri and its presumed avirulent variant. Can. J. Microbiol. 15:817-818.

6. Chun, J., and M. Goodfellow. 1995. A phylogenetic analysis of the genus Nocardia with 16S rRNA gene sequences. Int. J. Syst. Bacteriol. 45:240-245.

7. Collins, M. D., R. A. Burton, and D. Jones. 1988. Corynebacterium amycolatum sp. nov., a new mycolic acid-less Connebacterium species from human skin. FEMS Microbiol. Lett. 49:349-352.

8. Collins, M. D., and C. S. Cummins. 1986. Genus Corynebacterium Lehman and Neumann 1896, p. 1266-1276. In P. H. A. Sneath, N. S. Mair, M. E. Sharpe, and J. G. Holt (ed.), Bergey's manual of systematic bacteriology, vol. 2. The Williams and Wilkins Co., Baltimore.

9. Collins, M. D., M. Goodfellow, and D. E. Minnikin. 1982. Fatty acid composition of some mycolic acid-containing coryneform bacteria. J. Gen. Microbiol. 128:2503-2509.

10. Collins, M. D., J. Smida, M. Dorsch, and E. Stackebrandt. 1988. Tsukamurella gen. nov. harboring Corynebacterium paurometabolum and Rhodococcus aurantiacus. Int. J. Syst. Bacteriol. 38:385-391.

11. Covle, M. B., R. B. Leonard, D. J. Nowowiejski, A. Malekniazi, and D. J. Finn. 1993. Evidence of multiple taxa within commercially available reference strains of Corynebacterium xerosis. J. Clin. Microbiol. 31:1788-1793.

12. Cummins, C. S., and H. Harris. 1956. The chemical composition of the cell wall in some Gram-positive bacteria and its possible value as a taxonomic character. J. Gen. Microbiol. 14:583-600.

13. Fox, G. E., and E. Stackebrandt. 1987. The application of 16S rRNA cataloguing and $5 \mathrm{~S}$ rRNA sequencing in bacterial systematics. Methods Microbiol. 19:405-458.

14. Funke, G., S. Stubbs, M. Altwegg, A. Carlotti, and M. D. Collins. 1994 Turicella otitidis gen. nov., sp. nov., a coryneform bacterium isolated from patients with otitis media. Int. J. Syst. Bacteriol, 44:270-273.

15. Goodfellow, M. 1992. The family Nocardiaceae, p. 1188-1213. In A. Balows, H. G. Trüper, M. Dworkin, W. Harder, and K.-H. Schleifer (ed.), The prokaryotes, 2nd ed., vol. 2. Springer-Verlag, New York

16. Goodfellow, M., A. R. Beckham, and M. D. Barton. 1982. Numerical classification of Rhodococcus equi and related actinomycetes. J. Appl. Bacteriol. 53:199-207.

17. Goodfellow, M., J. Chun, S. Stubbs, and A. S. Tobili. 1994. Transfer of Nocardia amarae Lechevalier and Lechevalier 1974 to the genus Gordona as Gordona amarae comb. nov. Lett. Appl. Microbiol. 19:401-405.

18. Goodfellow, M., J. Zakrzewska-Czerwinska, E. G. Thomas, M. Mordarski, A. C. Ward, and A. L. James. 1991. Polyphasic taxonomic study of the genera Gordona and Tsukamurella including the description of Tsukamurella wratislaviensis sp. nov. Zentralbl. Bakteriol. Parasitenkd. Infektionskr. Hyg. Abt. 1 Orig. 275:162-178.

19. Groman, N., J. Schiller, and J. Russell. 1984. Corynebacterium ulcerans and Corynebacterium pseudotuberculosis responses to DNA probes derived from corynephage $\beta$ and Corynebacterium diphtheriae. Infect. Immun. 45:511-517.

20. Häggblom, M. M. L. J. Nohynek, N. J. Palleroni, K. Kronqvist, E.-L. Nurmiaho-Lassila, M. S. Salkinoja-Salonen, S. Klatte, and R. M. Kroppenstedt. 1994. Transfer of polychlorophenol-degrading Rhodococcus chlorophenolicus (Apalahti et al. 1986) to the genus Mycobacterium chlorophenolicum comb. nov. Int. J. Syst. Bacteriol. 44:485-493.

21. Huelsenbeck, J. P., and D. M. Hillis. 1993. Success of phylogenetic methods in the four-taxon case. Syst. Biol. 42:247-264.

22. Kämpfer, P., W. Dott, and R. M. Kroppenstedt. 1990. Numerical classification and identification of some nocardioform bacteria. J. Gen. Appl. Microbiol. 36:309-331.

23. Kim, J. 1993. Improving the accuracy of phylogenetic estimation by combin- 
ing different methods. Syst. Biol. 42:331-340.

24. Klatte, S., K.-D. Jahnke, R. M. Kroppenstedt, F. Rainey, and E. Stackebrandt. 1994. Rhodococcus luteus is a later subjective synonym of Rhodococcus fascians. Int. J. Syst. Bacteriol. 44:627-630.

25. Klatte, S., F. A. Rainley, and M. Kroppenstedt. 1994. Transfer of Rhodococcus aichiensis Tsukamura 1982 and Nocardia amarae Lechevalier and Lechevalicr 1974 to the genus Gordona as Gordona aichiensis comb. nov. and Gordona amarae comb. nov. Int. J. Syst. Bacteriol. 44:769-773.

26. Lechevalier, M. P., and H. Lechevalier. 1970. Chemical composition as a criterion in the classification of aerobic actinomycetes. Int. J. Syst. Bacteriol. 20:435-443

27. Liebl, W., M. Ehrmann, W. Ludwig, and K.-H. Schleifer. 1991. Transfer of Brevibacterium divaricatum DSM 20297", "Brevibacterium favum" DSM 20411, "Brevibacterium lactofermentum" DSM 20412 and DSM 1412, and Corynebacterium lilium DSM $20137^{\mathrm{T}}$ to Connebacterium glutamicum and their distinction by rRNA gene restriction patterns. Int. J. Syst. Bacteriol. 41:255-260.

28. Mordarski, M. M., M. Goodfellow, A. Tkacz, G. Pulverer, and K. P. Schaal. 1980. Ribosomal ribonucleic acid similarities in the classification of Rhodococcus and related taxa. J. Gen. Microbiol. 118:313-319.

29. Pitcher, D. G. 1983. Deoxyribonucleic acid base composition of Corynebacterium diphtheriae and other corynebacteria with cell wall chemotype IV. FEMS Microbiol. Lett. 16:291-295.

30. Pitulle, C., M. Dorsch, J. Kadzda, J. Wolters, and E. Stackebrandt. 1992. Phylogeny of rapidly growing members of the genus Mycobacterium. Int. J. Syst. Bacteriol. 42:337-343.

31. Rainey, F. A., J. Burghardt, R. M. Kroppenstedt, S. Klatte, and E. Stackebrandt. 1995. Phylogenetic analysis of the genera Rhodococcus and Nocardia and evidence for the evolutionary origin of the genus Nocardia from within the radiation of Rhodococcus species. Microbiology 141:523-528.

32. Rainey, F. A., J. Burghardt, R. M. Kroppenstedt, S. Klatte, and E. Stackebrandt. 1995. Polyphasic evidence for the transfer of Rhodococcus roseus to Rhodococcus rhodochrous. Int. J. Syst. Bacteriol. 45:101-103.

33. Rainey, F. A., S. Klatte, R. M. Kroppenstedt, and E. Stackebrandt. 1995. Dietzia, a new genus including Dietzia maris comb. nov., formerly Rhodococcus maris. Int. J. Syst. Bacteriol. 45:32-36.

34. Riegel, P., D. de Briel, G. Prévost, F. Jehl, and H. Monteil. 1993. Proposal of Corynebacterium propinquum sp. nov. for Corynebacterium group ANF-3 strains. FEMS Microbiol. Lett. 113:229-234.

35. Riegel, P., D. de Briel, G. Prévost, F. Jehl, H. Monteil, and R. Minck. 1993. Taxonomic study of Corynebacterium group ANF-1 strains: proposal of Connebacterium afermentans sp. nov. containing the subspecies $C$. afermentans subsp. afermentans subsp. nov. and $C$. afermentans subsp. lipophilum subsp. nov. Int. J. Syst. Bacteriol. 43:287-292.

36. Riegel, P., M. V. Kamne-Fotso, D. De Briel, G. Prévost, F. Jehl, Y. Piémont and H. Monteil. 1994. Rhodococcus chubuensis Tsukamura 1982 is a later subjective synonym of Gordona sputi (Tsukamura 1978) Stackebrandt 1989 comb. nov. Int. J. Syst. Bacteriol. 44:764-768.

37. Riegel, P., R. Ruimy, R. Christen, and H. Monteil. Unpublished data.

38. Riegel, P., R. Ruimy, D. De Briel, G. Prévost, F. Jehl, R. Christen, and H.
Monteil. 1995. Genomic diversity and phylogenetic relationships among lipid-requiring diphtheroids from humans and characterization of Corynebacterium macginleyi sp. nov. Int. J. Syst. Bacteriol. 45:128-133.

39. Riegel, P., R. Ruimy, D. De Briel, G. Prévost, F. Jehl, R. Christen, and H. Monteil. 1995. Taxonomy of Connebacterium diphtheriae and related taxa with recognition of Corynebacterium ulcerans sp. nov. nom. rev. FEMS Microbiol. Lett. 126:271-276.

40. Rogall, T., J. Wolters, T. Flohr, and E. C. Böttger. 1990. Towards a phylogeny and definition of species at the molecular level within the genus Mycobacterium. Int. J. Syst. Bacteriol. 40:323-330.

41. Ruimy, R., P. Boiron, V. Boivin, and R. Christen. 1994. A phylogeny of the genus Nocardia deduced from the analysis of small-subunit ribosomal DNA sequences, including transfer of Nocardia amarae to the genus Gordona as Gordona amarae comb. nov. FEMS Microbiol. Lett. 123:261-268.

42. Ruimy, R., V. Breittmayer, P. Elbaze, B. Lafay, O. Boussemart, M. Gauthier, and R. Christen. 1994. A general phylogenetic analysis of the family Vibrionaceae (Vibrio, Photobacterium, Aeromonas, Plesiomonas) deduced from the comparison of nearly complete $16 \mathrm{~S}$ rRNA sequences. Int. J. Syst. Bacteriol. 44:416-426.

43. Saitou, N., and M. Nei. 1987. The neighbor-joining method: a new method for reconstructing phylogenetic trees. Mol. Biol. Evol. 4:406-425.

44. Smith, A. B., B. Lafay, and R. Christen. 1992. Comparative variation of morphological and molecular evolution through geologic time: $28 \mathrm{~S}$ ribosomal RNA versus morphology in echinoids. Philos. Trans. R. Soc. Lond. B Biol. Sci. 338:365-382.

45. Sneath, P. H. A. 1993. Evidence from Aeromonas for genetic crossing-over in ribosomal sequences. Int. J. Syst. Bacteriol. 43:626-629.

46. Sritharan, V., and R. H. Barker. 1991. A simple method for diagnosing Mycobacterium tuberculosis infection in clinical samples using PCR. Mol. Cell. Probes 5:385-395.

47. Stackebrandt, E., W. Ludwig, E. Seewaldt, and K.-H. Schleifer. 1983. Phylogeny of sporeforming members of the order Actinomycetales. Int. J. Syst. Bacteriol. 33:173-180.

48. Stackebrandt, E., and C. R. Woese. 1981. Towards a phylogeny of the actinomycetes and related organisms. Curr. Microbiol. 5:197-202.

49. Stahl, D. A., and J. W. Urbance. 1990. The division between fast- and slow-growing species corresponds to natural relationships among the mycobacteria. J. Bacteriol. 172:116-124.

50. Suzuki, K., T. Kanebo, and K. Komagata. 1981. Deoxyribonucleic acid homologies among coryneform bacteria. Int. J. Syst. Bacteriol. 31:131-138.

51. Swofford, D. 1990. PAUP: phylogenetic analysis using parsimony, version 3.0. Illinois Natural History Survey, Champaign.

52. Warwick, S., T. Bowen, H. McVeigh, and M. Embley. 1994. A phylogenetic analysis of the family Pseudonocardiaceae and the genera Actinokineospora and Saccharothrix with $16 \mathrm{~S}$ rRNA sequences and a proposal to combine the genera Amycolata and Pseudonocardia in an emended genus Pseudonocardia. Int. J. Syst. Bacteriol. 44:293-299.

53. Yanagawa, R., and E. Honda. 1978. Connebacterium pilosum and Corynebacterium cystitidis, two new species from cows. Int. J. Syst. Bacteriol. 28: 209-216. 